\title{
MECHANICAL HYPERNOCICEPTION IN EXPERIMENTAL AUTOIMMUNE ENCEPHALOMYELITIS
}

\author{
David Henrique Rodrigues', Daniela Sachs', Antonio Lucio Teixeira ${ }^{1,2}$
}

\begin{abstract}
Background: Pain is an important clinical manifestation in multiple sclerosis (MS) patients, though it has been neglected in clinical and experimental researches. Objective: To investigate the nociceptive response in $\mathrm{MOG}_{35-55}$ experimental autoimmune encephalomyelitis (EAE)-induced mice. Method: EAE was induced in 8 to 10 week old C57BL/ 6 female mice with an emulsion of $\mathrm{MOG}_{35-55}$, Complete Freund Adjuvant, Mycobacterium tuberculosis H37 RA and pertussis toxin. Nociception was evaluated by the von Frey filaments method. A clinical scale ranging from 0 to 15 was used to assess motor impairment. Results: Clinical evidence of disease started at day 10 and peaked at day 14 after immunization. Thereafter, there was no worsening of symptoms until day 26. The EAE-induced mice presented reduced pressure threshold at days $7^{\text {th }}$ and $10^{\text {th }}$ after immunization and before the onset of clinical motor signs. Conclusion: The hypernociception found validates $M O G_{35-55}$ EAE as a model for the study of pain in multiple sclerosis.
\end{abstract}

KEY WORDS: multiple sclerosis; experimental autoimmune encephalomyelitis, hyperalgesia, mechanical hypernociception.

\begin{abstract}
Hipernocicepção mecânica em encefalomielite autoimune experimental
Resumo - Introdução: Dor é uma manifestação importante em pacientes com esclerose múltipla (EM), mas que tem sido negligenciada na pesquisas clínica e experimental. Objetivo: Investigar a resposta nociceptiva de camundongos com encefalomielite autoimune experimental (EAE) induzida por $\mathrm{MOG}_{35-55}$. Método: A EAE foi induzida em camundongos C57BL/ 6 fêmeas de 8-10 semanas com emulsão contendo MOG $_{35-55}$, Adjuvante Completo de Freund, Mycobacterium tuberculosis cepa H37 RA e toxina pertussis. A nocicepção foi medida pelo método de filamentos de von Frey. Uma escala clínica variando de 0 a 15 foi utilizada para avaliar a debilidade motora dos animais. Resultados: Os sinais clínicos da doença iniciaram-se no dia 10 e a gravidade máxima foi alcançada no dia 14 após a imunização. Não houve piora dos sintomas até o dia 26 . Os camundongos induzidos com EAE apresentaram diminuição do limiar de pressão nos dias 7 e 10 após a imunização e antes do início dos sinais motores. Conclusão: A hipernocicepção verificada valida a EAE induzida por $\mathrm{MOG}_{35-55}$ como um modelo para estudos de dor em esclerose múltipla.
\end{abstract}

PALAVRAS-CHAVE: esclerose múltipla; encefalomielite autoimune experimental, hiperalgesia; hipernocicepção mecânica.

Multiple sclerosis (MS) is considered an autoimmune inflammatory disease affecting 2.5 million people worldwide. Its defining feature is the central nervous system (CNS) demyelinating lesions in association with inflammatory infiltrates. Axonal injury can also occur'. Clinical signs of MS include sensory disturbances, optic neuritis, diplopia, Lhermitte's sign, limb weakness, clumsiness, gait ataxia, neurogenic bladder, bowel symptoms and also pain². Although many MS patients describe pain as their worst symptom ${ }^{3}$, only recently pain has been systematically studied in MS patients ${ }^{4,5}$. Pain in MS can be ascribed to a variety of conditions such as musculoskeletal pain, painful spasms, trigeminal neuralgia, and central pain due to sclerotic plaque lesions affecting sensorial pathways in the $\mathrm{CNS}^{4}$.

In the search of a better understanding of MS, investigators have been using many experimental models, including the experimental autoimmune encephalomyelitis (EAE). EAE can be induced in susceptible species by

\footnotetext{
'Laboratório de Imunofarmacologia, Departamento de Bioquímica e Imunologia, Instituto de Ciências Biológicas, Universidade Federal de Minas Gerais, Belo Horizonte MG, Brasil; ${ }^{2}$ Grupo de Neurologia, Departamento de Clínica Médica da Faculdade de Medicina da Universidade Federal de Minas Gerais, Belo Horizonte MG, Brasil. This work was funded by grants from Conselho Nacional de Desenvolvimento Científico e Tecnológico (CNPq) and Rede Instituto Brasileiro de Neurociência (IBN Net/Finep), Brazil.
}

Received 7 August 2008, received in final form 20 October 2008. Accepted 29 November 2008.

Dr. Antonio Lucio Teixeira - Departamento de Clínica Médica / Faculdade de Medicina da UFMG - Avenida Prof. Alfredo Balena 190 - $30130-100$ Belo Horizonte MG - Brasil. E-mail: altexr@gmail.com 
many different protocols usually with an emulsion containing one of these three molecules: MBP (myelin basic protein), PLP (proteolipid protein) or MOG (myelin oligodendrocyte glycoprotein) ${ }^{6}$. In spite of the relevance of pain in MS, there are only a few studies investigating pain in $\mathrm{EAE}$, none related to $\mathrm{MOG}_{35}-55$-induced EAE.

Hence, in the present study, we intended to investigate whether $\mathrm{MOG}_{35-55} \mathrm{EAE}$-induced mice had altered mechanical nociception.

\section{METHOD}

Animals

Animal care and handling procedures were in accordance with the guidelines of the International Association for Study of Pain and had prior approval from the local animal ethics committee (Comitê de Ética em Experimentação Animal, CETEA/UFMG, Certificate number 007/2007). Eight to 10 weeks old female C57Bl/6J (WT) mice were obtained from Centro de Bioterismo (CEBIO) of the Universidade Federal de Minas Gerais (UFMG, Brazil) and maintained in the animal facilities of the Laboratory of Immunopharmacology, Department of Biochemistry and Immunology (UFMG, Brazil), with filtered water, food ad libitum and in a controlled environment (temperature and humidity). Animals were divided in two groups: $\mathrm{MOG}_{35-55} \mathrm{EAE}$ induced mice $(n=8)$ and control mice injected with saline $(n=8)$.

\section{EAE induction}

EAE was induced by s.c. immunization (base of tail) with an emulsion containing $100 \mu \mathrm{g} \mathrm{MOG}_{35-55}$ peptide (MEVGWYRSPFSRVVHLYRNGK; NeoMPS) and CFA supplemented with $4 \mathrm{mg} / \mathrm{mL}$ Mycobacterium tuberculosis H37 RA (Difco Laboratories). Pertussis toxin, $300 \mathrm{ng} /$ animal was injected i.p. on the day of immunization and again $48 \mathrm{~h}$ later $^{7}$.

\section{Daily assessments of disease in mice}

Animals were evaluated daily using a previously described scale $e^{8}$. This scale ranges from 0 to 15 and is the sum of the state of the tail and all of the four limbs. For the tail, a score of 0 reflects no sign, 1 represents a partial paralyzed tail, while a score of 2 is given to a mouse with a fully paralyzed tail. For each of the hind- or forelimbs, each assessed separately, 0 signifies no sign, a score of 1 is an altered gait, 2 represents paresis, while a score of 3 denotes a fully paralyzed limb. Thus, a fully paralyzed quadriplegic animal would attain a score of 14. Mortality equals a score of 15 . Typically, a mouse undergoing an attack would first have loss of function in the tail followed by one of the hindlimbs. Therefore, a low score of 3 or 4 indicates tail involvement and a weak hindlimb, akin to Grade 2 on the commonly used 5 point scale 9 . Animals were also weighed daily.

\section{Nociceptive mechanical test}

The term "hypernociception" was used to define the decrease of nociceptive withdrawal threshold ${ }^{10}$. Mechanical hypernocicep- tion was tested in mice as reported previously ${ }^{11,12}$. Briefly, in a quiet room, mice were placed in $12 \times 10 \times 17-\mathrm{cm}$ acrylic cages with wire grid floors 15-30 min before the start of testing. The test consisted of evoking a hindpaw flexion reflex with a hand-held force transducer (Electronic Anesthesiometer, Insight mod. EFF301 , Brazil) adapted with a $0.5-\mathrm{mm}^{2}$ polypropylene tip. The investigator was trained to apply the tip perpendicularly to the central area of the hindpaw with a gradual increase in pressure. The endpoint was characterized by the removal of the paw, followed by clear flinching movements. After the paw withdrawal, the intensity of the pressure was automatically recorded. The value for the response was obtained by averaging three measurements. Animals were tested before and after treatments. Results are expressed as $\Delta$ withdrawal threshold (in g) calculated by subtracting zero-time mean measurements from the time interval mean measurements.

\section{Statistical analysis}

Results are shown as the mean \pm SD. Difference among groups was evaluated by using analysis of variance (ANOVA) followed by Student-Newman-Keuls post-hoc test. The level of significance was set a $\mathrm{p}<0.05$.

\section{RESULTS}

\section{Kinetics of clinical changes in EAE mice}

The severity of $\mathrm{MOG}_{35-55}$-induced EAE was assessed daily using a previously validated scale ${ }^{8}$. Clinical evidence of disease was first noticed at day 10 and peaked at day 14 after immunization. Thereafter, there was no worsening of symptoms till day 26 (Fig 1A). Tail paralysis and hind limb weakness was the major clinical feature noticed. Paralleling the clinical symptoms above, there was significant weight loss which peaked at day 14 after disease induction when compared with control mice (Fig 1B).

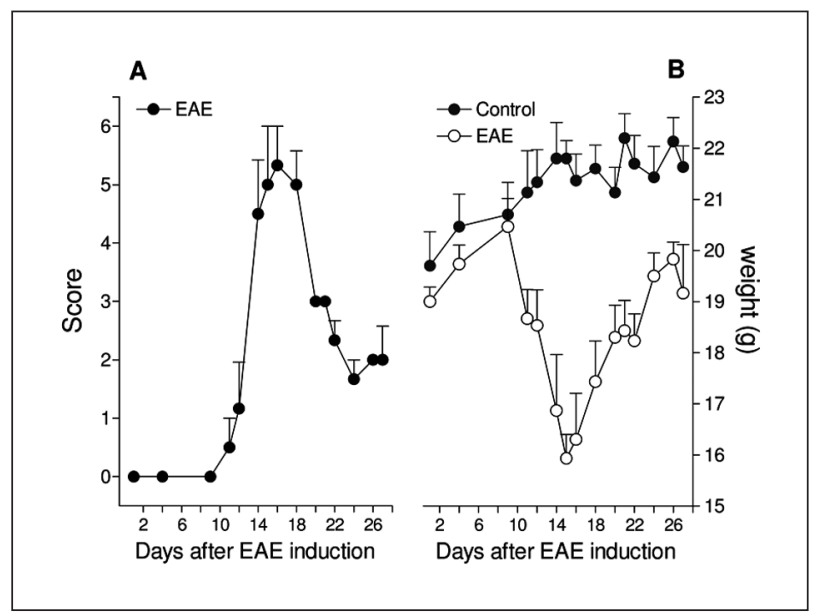

Fig 1. Experimental autoimmune encephalomyelitis (EAE) clinical signs (A) and body weights loss (B) were monitored in control and EAE-induced mice. This kinetics study includes the time points 1 to 26 day post-induction of EAE with MOG35-55. Data is according to maximal clinical score achieved at any time during experimental design. The data are the means $( \pm S D)$ of eight animals per group. 


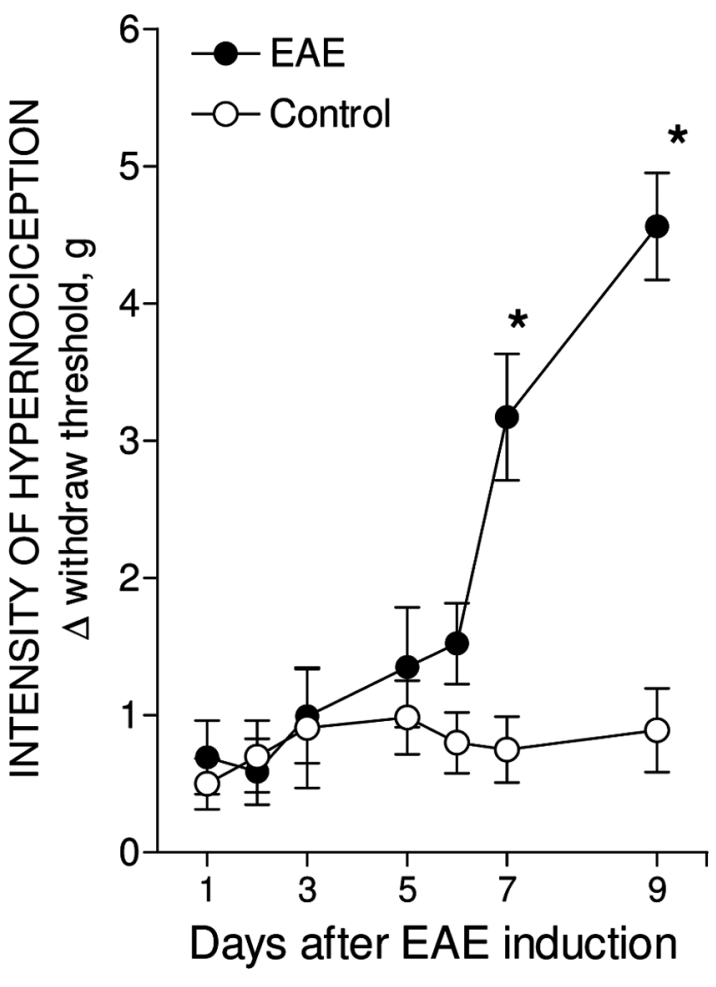

Fig 2. MOG $35-55$-induced mechanical hypernociception. The intensity of mechanical hypernociception was assessed daily in experimental autoimmune encephalomyelitis (EAE) and control mice. The data are the means $( \pm S D)$ of eight animals per group. Asterisks denote statistically significant differences compared with the control group $(p<0.05)$.

\section{MOG $_{35-55}$-induced mechanical hypernociception}

The immunization of mice with $\mathrm{MOG}_{35-55}$ peptide brought about a mechanical hypernociception. The intensity of hypernociception was assessed daily in EAE and control mice. The mechanical hypernociception was observed in EAE mice on the $7^{\text {th }}$ and $10^{\text {th }}$ days after immunization (Fig 2). The intensity of hypernociception was assessed before clinical evidence of disease that was first noticed at day 10 . We did not evaluate mechanical nociception after 10 days, as the results could be affected by the motor condition of the animals.

\section{DISCUSSION}

To the best of our knowledge, this is the first study of nociception in $\mathrm{MOG}_{35-55}$-induced $\mathrm{EAE}$ in $\mathrm{C} 57 \mathrm{BL} / 6$ mice. We found hypernociception in EAE mice before the onset of motor disability.

Hypernociception was also found in a recent study ${ }^{13}$ which observed thermal hyperalgesia and mechanical allodynia during disease progression in the Theiler's virus experimental model of MS (Theiler's murine encephalo- myelitis virus, TMEV). The TMEV model displays a clinical outcome similar to MS, but the autoimmune response observed in MS is not described for this experimental model. By contrast, EAE presents many pathophysiological similarities to MS and is considered a more suitable model for this CNS disease ${ }^{14}$.

A previous study ${ }^{15}$ found hyponociception and hypernociception during acute and chronic phases, respectively, using a heat stimulus method. In that study, the investigators used a PLP-induced EAE model and evaluated nociception after the onset of clinical disability, which could have interfered with results. The hypernociception found in the chronic phase of EAE may suggest that the PLPinduced model is a good model to evaluate chronic pain, which is also found in $\mathrm{MS}^{16}$. However, that model was unable to detect acute pain, a common problem for many MS patients ${ }^{17,18}$. We described hypernociception before the onset of clinical impairment using the $\mathrm{MOG}_{35-55} \mathrm{EAE}$ model. Therefore this could be a better model to study acute pain in MS. As the animals had severe motor impairment after onset of clinical signs, we avoided the measurement of nociception after 10 days of EAE induction.

A study using an EAE model of Lewis rats found hyponociception during acute phase of disease using a vocalization method of response to noxious mechanical stimulation of the tail ${ }^{19}$. They concluded that hyponociception was due to demyelination of small diameter fibres in the sacrococcygeal dorsal root ganglia, dorsal roots and dorsal root entry zones. However, in our EAE model, demyelination is not so evident, especially before the onset of clinical signs ${ }^{20}$. Hence, the hypernociception observed in our results may be caused by other pathways.

Immune response before onset of clinical signs in this experimental model of MS is evidenced by several studies. Increased rolling of leukocytes ${ }^{7}$ and increase of $\mathrm{CD}^{+} \mathrm{T}$ cells in draining lymph nodes ${ }^{21}$ after 7 days postimmunization; increase of P-selectin in CNS after 8 days post-immunization ${ }^{22}$ and increase in IFN- $\gamma$ after 10 days post-immunization ${ }^{23}$ are some of the immune events that happen before motor disability of the animals. Thus, the hypernociception observed in our study may be the result of the intrinsic immune response from the $7^{\text {th }}$ to the $10^{\text {th }}$ day after immunization. Cytokines were found to mediate hypernociception in a carrageenan-induced inflammatory model of hyperalgesia ${ }^{10}$ and chemokines (chemotactic cytokines) seem to be involved in the hypernociception elicited by an experimental model of arthritis ${ }^{24}$. Chemokines are also important in $\mathrm{MS}^{25,26}$ and they are involved in many pathways of pain ${ }^{27}$. The possibility of chemokines being the cause of pain in MS was discussed elsewhere ${ }^{28}$. Nonetheless, further studies are needed to investigate 


\section{whether cytokines or other immune factors are involved in the hypernociception of $\mathrm{MOG}_{35-55}$ EAE mice.}

In conclusion, the hypernociception observed indicates that the $\mathrm{MOG}_{35-55}$ EAE model may be a useful tool to study the mechanisms of pain in MS.

\section{REFERENCES}

1. Hafler D. Multiple sclerosis. J Clin Invest 2004;113:788-794.

2. Noseworthy JH, Lucchinetti C, Rodriguez M, Weinshenker BG. Multiple sclerosis. N Engl J Med 2000;343:938-952.

3. Beard S, Hunn A, Wight J. Treatments for spasticity and pain in multiple sclerosis: a systematic review. Health Technol Assess 2003;7:1-124.

4. Svendsen KB, Jensen TS, Hansen HJ, Bach FW. Sensory function and quality of life in patients with multiple sclerosis and pain. Pain 2005;114: 473-481.

5. O'Connor AB, Schwid SR, Herrmann DN, Markman JD, Dworkin RH. Pain associated with multiple sclerosis: systematic review and proposed classification. Pain 2008;137:96-111.

6. Gold A, Linington C, Lassmann $\mathrm{H}$. Understanding pathogenesis and therapy of multiple sclerosis via animal models: 70 years of merits and culprits in experimental autoimmune encephalomyelitis research. Brain 2006;129:1953-1971.

7. Santos AC, Barsante MM, Arantes RME, Bernard CCA, Teixeira MM. Carvalho-Tavares J. CCL2 and CCL5 mediate leukocyte adhesion in experimental autoimmune encephalomyelitis: an intravital microscopy study. J Neuroimmunol 2005;162:122-129.

8. Weaver A, Silva AG, Nuttall RK et al. An elevated matrix metalloproteinase (MMP) in an animal model of multiple sclerosis is protective by affecting Th1/Th2 polarization. FASEB J 2005;19:1668-1670.

9. Brundula V, Rewcastle NB, Metz LM, Bernard CC, Yong VW. Targeting leukocyte MMPs and transmigration: minocycline as a potential therapy for multiple sclerosis. Brain 2002;125:1297-1308.

10. Cunha TM, Verri WA Jr, Silva JS, Poole S, Cunha FQ, Ferreira SH. A cascade of cytokines mediates mechanical inflammatory hypernociception in mice. Proc Natl Acad Sci USA 2005;102:1755-1760.

11. Vivancos GG, Verri WA Jr, Cunha TM, et al. An electronic pressure-meter nociception paw test for rats. Braz J Med Biol Res 2004;37:391-399.

12. Coelho FM, Pinho V, Amaral FA, et al. The chemokine receptors CXCR1/2 modulate antigen-induced arthritis by regulating adhesion of neutrophils to the synovial microvasculature. Arthritis Rheum 2008; 58:2329-2337.
13. Lynch JL, Gallus NJ, Ericson ME, Beitz AJ. Analysis of nociception, sex and peripheral nerve innervation in the TMEV animal model of multiple sclerosis. Pain 2008;136:293-304.

14. Steinman L, Zamvil SS. Virtues and pitfalls of EAE for the development of therapies for multiple sclerosis. Trends Immunol 2005;26:565-571.

15. Aicher SA, Silverman MB, Winkler CW, Bebo BF. Hyperalgesia in an animal model of multiple sclerosis. Pain 2004;110:560-570.

16. Moulin D, Foley K, Ebers G. Pain syndromes in multiple sclerosis. Neurology 1988;38:1830-1834

17. Indaco A, Iachetta C, Socci L, Carrieri PB. Chronic and acute pain syndromes in patients with multiple sclerosis. Acta Neurol 1994;16:97-102.

18. Stenager E, Knudsen L, Jensen K. Acute and chronic pain syndromes in multiple sclerosis. Acta Neurol Scand 1991;84:197-200.

19. Pender MR. Ascending impairment of nociception in rats with experimental allergic encephalomyelitis. J Neurol Sci 1986;75:317-328.

20. Jones MV, Nguyen TT, Deboy CA, et al. Behavioral and pathological outcomes in MOG 35-55 experimental autoimmune encephalomyelitis. J Neuroimmunol 2008;199:83-93.

21. Wang Y, Kai H, Chang F, et al. A critical role of LFA-1 in the development of Th17 cells and induction of experimental autoimmune encephalomyelitis. Biochem Biophys Res Commun 2007;353:857-862.

22. Kerfoot SM, Kubes P. Overlapping roles of p-selectin and $\alpha 4$ integrin to recruit leukocytes to the central nervous system in experimental autoimmune encephalomyelitis. J Immunol 2002;169:1000-1006.

23. Huang DR, Wang J, Kivisakk P, Rollins BJ, Ransohoff RM. Absence of monocyte chemoattractant protein 1 in mice leads to decreased local macrophage recruitment and antigen-specific $\mathrm{T}$ helper cell type $1 \mathrm{im}-$ mune response in experimental autoimmune encephalomyelitis. J Exp Med 2001;193:713-725.

24. Barsante MM, Roffê E, Yokoro CM, et al. Anti-inflammatory and analgesic effects of atorvastatin in a rat model of adjuvant-induced arthritis. Eur J Pharmacol 2005;516:282-289.

25. Moreira MA, Tilbery CP, Monteiro LP, Teixeira MM, Teixeira AL. Effect of the treatment with methylprednisolone on the cerebrospinal fluid and serum levels of CCL2 and CXCL10 chemokines in patients with active multiple sclerosis. Acta Neurol Scand 2006;114:109-113.

26. Moreira MA, Souza AL, Lana-Peixoto MA, Teixeira MM, Teixeira AL Chemokines in the cerebrospinal fluid of patients with active and stable relapsing-remitting multiple sclerosis. Braz J Med Biol Res 2006;39: 441-445.

27. White FA, Jung H, Miller RJ. Chemokines and the pathophysiology of neuropathic pain. Proc Natl Acad Sci USA 2007;104:20151-20158.

28. Sachs D, Teixeira AL. Up-regulation of chemokines and their receptors may contribute to pain in multiple sclerosis. Med Hypotheses 2008;71: 466-467. 